\title{
Nonsteroidal anti-inflammatory drugs and their risk: a story still in development
}

\author{
Lee S Simon*
}

NSAIDs are anti-inflammatory, analgesic, and antipyretic agents, and they are typically used chronically to reduce pain, decrease stiffness, and improve function in patients with osteoarthritis, rheumatoid arthritis, and other forms of arthritis. Additionally, NSAIDs are also used for the more acute treatment of pain including headache, dysmenorrhea, and postoperative pain [1-4]. However, NSAID use conveys potential significant adverse events that include gastrointestinal ulcers with consequential bleeding, perforation or obstruction, renal dysfunction and consequent renal failure, cardiovascular events, as well as the risk for death [5-11]. Despite the many available forms of NSAIDs, including injectable as well as topical, oral dosing is the most common route, usually the one route consistently associated with chronic use and thus the one that carries the most risk. In the last several years, several topical NSAIDs including either diclofenac ibuprofen or salicylates for chronic pain have been approved in the United States while similar drugs have been available in Europe for years. One study of a diclofenac topical liquid included an oral diclofenac comparator, and demonstrated no difference in efficacy between the two therapies in treatment for the pain of osteoarthritis in the knee [12].

The risk for potential gastrointestinal damage due to systemic exposure of NSAIDs is well defined, including gastrointestinal symptoms such as dyspepsia and abdominal pain, increased incidence of endoscopic ulcers, bleeding, and death. A history of prior gastrointestinal symptoms or bleeding, the presence of other risk factors such as advancing age, higher doses of NSAID, duration of NSAID use, as well as the frailty of the patient all increase the risk for upper gastrointestinal damage and consequent bleeding [13]. Use of NSAIDs with a longer half-life probably places patients at greater risk of adverse events.

Strategies to decrease the risk for damage to the gastrointestinal tract have included the transition to

*Correspondence: Issconsult@aol.com

SDG LLC, One Mifflin Place, Suite 400, Cambridge, MA 02138, USA other types of drugs, use of lower dose systemic NSAIDs, and the use of topical NSAIDs, but there are still patients who require more chronic exposure to higher dose therapy. In addition, other strategies include the addition of prostaglandin analogues, $\mathrm{H}_{2}$ receptor antagonists, or proton pump inhibitors as concomitant therapies [1418]. More recently, combination products have been developed $[19,20]$. This supplement will review the continued importance of NSAIDs as part of a strategy to continue to treat pain adequately as well as the attempts to mitigate the risks associated with the use of these drugs.

Abbreviations

NSAID, nonsteroidal anti-inflammatory drug.

\section{Competing interests}

LSS serves as a clinical and regulatory consultant in drug development and has served as such consultant for companies which manufacture and market NSAIDs including Pfizer, Pozen, Horizon Pharma, Logical Therapeutics, Nuvo Research, Iroko, Imprimis, JRX Pharma, Nuvon, Medarx, and Asahi.

\section{Declaration}

This article has been published as part of Arthritis Research \& Therapy Volume 15 Suppl 3, 2013: 'Gastroprotective NSAIDS'. The full contents of the supplement are available online at http://arthritis-research.com/ supplements/15/S3. The supplement was proposed by the journal and developed by the journal in collaboration with the Guest Editor. The Guest Editor assisted the journal in preparing the outline of the project but did not have oversight of the peer review process. The Guest Editor serves as a clinical and regulatory consultant in drug development and has served as such consultant for companies which manufacture and market NSAIDs including Pfizer, Pozen, Horizon Pharma, Logical Therapeutics, Nuvo Research, Iroko, Imprimis, JRX Pharma, Nuvon, Medarx, Asahi. The articles have been through the journal's standard peer review process. Publication of this supplement has been supported by Horizon Pharma Inc. Duexis (ibuprofen and famotidine) is a product marketed by the sponsor.

Published: 24 July 2013

\section{References}

1. Brooks PM, Day RO: Nonsteroidal antiinflammatory drugs: differences and similarities. N Engl J Med 1991, 324:1716-1725.

2. Furst DE: Are there differences among nonsteroidal antiinflammatory drugs? Comparing acetylated salicylates, nonacetylated salicylates, and nonacetylated nonsteroidal antiinflammatory drugs. Arthritis Rheum 1994, 37:1-9.

3. Simon LS: Actions and toxicities of nonsteroidal anti-inflammatory drugs. Curr Opin Rheumatol 1996, 8:169-175.

4. Hawkey CJ: COX-2 inhibitors. Lancet 1999, 353:307-314.

5. Tramèr MR, Moore RA, Reynolds DJ, McQuay HJ: Quantitative estimation of rare adverse events which follow a biological progression: a new model applied to chronic NSAID use. Pain 2000, 85:169-182. 
6. Hawkey CJ: Cyclooxygenase inhibition: between the devil and the deep blue sea. Gut 2002, 50(Suppl 3):||I25-III30.

7. Hernández-Díaz S, Rodríguez LA: Association between nonsteroidal antiinflammatory drugs and upper gastrointestinal tract bleeding/ perforation: an overview of epidemiologic studies published in the 1990s. Arch Intern Med 2000, 160:2093-2099.

8. Massó González EL, Patrignani P, Tacconelli S, García Rodríguez LA: Variability among nonsteroidal antiinflammatory drugs in risk of upper gastrointestinal bleeding. Arthritis Rheum 2010, 62:1592-1601.

9. Lewis SC, Langman MJ, Laporte JR, Matthews JN, Rawlins MD, Wiholm BE: Dose-response relationships between individual nonaspirin nonsteroidal anti-inflammatory drugs (NANSAIDs) and serious upper gastrointestinal bleeding: a meta-analysis based on individual patient data. $\mathrm{Br} J \mathrm{Clin}$ Pharmacol 2002, 54:320-326.

10. Lanas A, García-Rodríguez LA, Arroyo MT, Gomollón F, Feu F, González-Pérez A, Zapata E, Bástida G, Rodrigo L, Santolaria S, Güell M, de Argila CM, Quintero E, Borda F, Piqué JM; Asociación Española de Gastroenterología: Risk of upper gastrointestinal ulcer bleeding associated with selective cyclooxygenase-2 inhibitors, traditional non-aspirin non-steroidal antiinflammatory drugs, aspirin and combinations. Gut 2006, 55:1731-1738.

11. García Rodríguez LA, Barreales Tolosa L: Risk of upper gastrointestinal complications among users of traditional NSAIDs and COXIBs in the general population. Gastroenterology 2007, 132:498-506.

12. Simon LS, Grierson LM, Naseer Z, Bookman AA, Zev Shainhouse J: Efficacy and safety of topical diclofenac containing dimethyl sulfoxide (DMSO) compared with those of topical placebo, DMSO vehicle and oral diclofenac for knee osteoarthritis. Pain 2009, 143:238-245.

13. Simon LS, Hatoum HT, Bittman RM, Archambault WT, Polisson RP: Risk factors for serious nonsteroidal-induced gastrointestinal complications: regression analysis of the MUCOSA trial. Fam Med 1996, 28:202-208.

14. Brown TJ, Hooper L, Elliott RA, Payne K, Webb R, Roberts C, Rostom A, Symmons D: A comparison of the cost-effectiveness of five strategies for the prevention of non-steroidal anti-inflammatory drug-induced gastrointestinal toxicity: a systematic review with economic modelling. Health Technol Assess 2006, 10:iii-iv, xi-xiii, 1-183.
15. Taha AS, Hudson N, Hawkey CJ, Swannell AJ, Trye PN, Cottrell J, Mann SG, Simon TJ, Sturrock RD, Russell RI: Famotidine for the prevention of gastric and duodenal ulcers caused by nonsteroidal antiinflammatory drugs. NEngl J Med 1996, 334:1435-1439.

16. Cullen D, Bardhan KD, Eisner M, Kogut DG, Peacock RA, Thomson JM, Hawkey $\mathrm{CJ}$ : Primary gastroduodenal prophylaxis with omeprazole for nonsteroidal anti-inflammatory drug users. Aliment Pharmacol Ther 1998, 12:135-140.

17. Graham DY, Agrawal NM, Campbell DR, Haber MM, Collis C, Lukasik NL, Huang B; NSAID-Associated Gastric Ulcer Prevention Study Group: Ulcer prevention in long-term users of nonsteroidal anti-inflammatory drugs: results of a double-blind, randomized, multicenter, active- and placebocontrolled study of misoprostol vs lansoprazole. Arch Intern Med 2002, 162:169-175.

18. Hawkey CJ, Karrasch JA, Szczepañski L, Walker DG, Barkun A, Swannell AJ, Yeomans ND: Omeprazole compared with misoprostol for ulcers associated with nonsteroidal antiinflammatory drugs. Omeprazole versus Misoprostol for NSAID-induced Ulcer Management (OMNIUM) Study Group. NEng/ J Med 1998, 338:727-734

19. Goldstein JL, Hochberg MC, Fort JG, Zhang Y, Hwang C, Sostek M: Clinical trial: the incidence of NSAID-associated endoscopic gastric ulcers in patients treated with PN 400 (naproxen plus esomeprazole magnesium) vs. enteric-coated naproxen alone. Aliment Pharmacol Ther 2010, 32:401-413.

20. Laine L, Kivitz AJ, Bello AE, Grahn AY, Schiff MH, Taha AS: Double-blind randomized trials of single-tablet ibuprofen/high-dose famotidine vs. ibuprofen alone for reduction of gastric and duodenal ulcers. Am J Gastroenterol 2012, 107:379-386.

\section{doi:10.1186/ar4173}

Cite this article as: Simon LS: Nonsteroidal anti-inflammatory drugs and their risk: a story still in development. Arthritis Research \& Therapy 2013, 15(Suppl 3):S1. 